\title{
Economic Stimulus Programs Due to Covid-19: Perceptions, Participation and Progress for Black-Owned Small Businesses
}

\author{
Sally Sledge, Ph.D. \\ School of Business \\ Norfolk State University \\ 700 Park Ave., BMH 304.05 \\ Norfolk, VA 23504 \\ Email: sasledge@nsu.edu \\ USA
}

\section{ABSTRACT}

The COVID-19 virus has impacted every economic segment and demographic in the world in 2020. Especially hard hit has been small businesses, which often are working day to day to cover costs and remain profitable. In the United States, minority-owned businesses have been more severely impacted than other businesses and in particular, Blackowned businesses have experienced more negative impacts due to the pandemic when compared to their counterparts. This paper will highlight some of the issues and challenges faced by Black small businesses in response to a survey regarding the pandemic. Suggestions and recommendations will be given to assist these firms in recovery and growth.

\section{Keywords: Black-owned business, COVID-19, small business.}

\section{INTRODUCTION}

Small businesses were flying high in 2019 in the United States. At the time, there were over 30 million small businesses in the U.S. and they had been the primary engines of growth and innovation for the U.S. economy for decades (National Resources, 2020). In recent years, these businesses typically created about 1.5 million jobs annually, which represented about $67 \%$ of all new jobs (Shepherd, 2019).

In 2019, 99\% of all businesses in the United States were small businesses (less than 500 employees, though many were much smaller) that fostered competitiveness while generating about $45 \%$ of all economic activity and employing nearly half of all workers in the country. (Small Business Statistics, 2019). In particular, minority business ownership numbered over 1 million companies in 2019 and approximately $33 \%$ of Black-owned businesses were in the important social services and health care sectors. (ABS, U.S. Census, 2019).

However, when the Coronavirus hit in March of 2020, the landscape changed drastically. By December, approximately $25 \%$ of all small businesses had closed nationwide (Rogers, 2020). Despite their successes, small businesses have had a long history of having trouble keeping the bottom line healthy. According to McKinsey and Company, about 33\% of small businesses were operating at or near a loss before the pandemic. Small businesses in key industries, such as education, healthcare, entertainment, the arts, recreation, food, and lodging account for $12 \%$ of U.S. business revenues. These businesses were more vulnerable to the effects of the pandemic as they had significant numbers of hourly workers, minority business owners, and lower-skilled employees, all of whom were greatly impacted by the outbreak (Mahajan, 2020).

While small businesses had been growing in number and influence since the early 2000s, many were unprepared to deal with such major market disruption. Unfortunately, minority-owned businesses experienced more significant losses than other similar businesses due to environmental and situational factors, such as location and customer bases. Almost half of the Black small businesses had to close their doors by summer, and Black-owned businesses were more than twice as likely to close permanently due to the pandemic, according to the New York Federal Reserve Bank (Effects of COVID, 2020). The New York Times reported that most of the Black-owned small businesses that closed in the New York area were located in the regions with the highest COVID rates, which led to economic and healthcare crises (Macro Issues, 2020).

Additional challenges for this demographic include the fact that unemployment rates for Black Americans have been frequently recorded as twice those of White Americans in the 2010s in the U.S. The numbers of COVID-19 cases are larger in the Black community, as many workers in this demographic are in front-line jobs (Kendi, 2020). In Chicago and many other cities, Black deaths due to COVID accounted for more fatalities than were proportionate to the population percentage (Gutierrez, 2020). Also in most states, the percentage of Black and Hispanic Americans with underlying health conditions which may exacerbate the impact of the virus on their longterm health is greater than in other demographics, such as Asians or Whites. Many Black businesses are located in Black communities, thus the problems of community health, economic sustainability, and business failure are multiplied in these areas. (Effects of COVID, 2020)

A survey from the University of California Santa Cruz stated that nearly $50 \%$ of Black-owned businesses went under in the first 6 months of the pandemic (Black Businesses, 2020). Many Black entrepreneurs have chosen to operate in the food and beverage segments. The Independent Restaurant 
Coalition (IRC) estimated that 1 in 6 restaurants in the U.S. closed indefinitely due to the Coronavirus. The group also said that many of the Federal assistance programs, such as the Paycheck Protection Program (PPP), were too limiting to allow all types of restaurants to benefit from them. Thus, more legislation is needed to address the obstacles these businesses face (Statements and Letters, 2020).

CNBC found that only $20 \%$ of PPP loans were distributed to geographic regions with the largest concentrations of Black-owned businesses. Reasons for the disparity in the allocation of funds include not maintaining an existing banking relationship, and not having strong local banks in the area. In some Black communities, these factors result in a lack of banks that work with small businesses and access to credit, where the banks act as liaisons for federal and state relief programs, including the PPP (Cox, 2020).

Certain regions of the country fared better than others due to the outbreak, and the effects of the virus vary depending on the season and month. In the mid-Atlantic region, Virginia has done better than most other states, in part because Governor Ralph Northam (D) is a medical doctor who has been proactive with government requirements and restrictions. The strong military presence and sound state budget also helped the state stay on top of the virus-fighting efforts (Quickfacts, 2020). However, the Commonwealth still saw major adverse impacts on commerce and trade.

From the 2010 Census, Virginia had the 9th largest minority-owned business population among the 50 states. There were over 40,000 Black-owned businesses in the state at that time, which generated approximately $\$ 3.7$ billion in receipts and sales (Gladden, 2010). With the increasing diversity in the country and the state, it makes sense to focus on these engines of growth and innovation, and help them succeed. Also, the rise in buying power from people of color in the last decade indicates a key market segment the deserves scholarly inquiry.

As a result of the huge challenges faced by Blackowned small businesses, their future success is at risk. Therefore, this research paper will shed light on this issue by presenting the results of an exploratory survey for this demographic group from 2020. The findings will be shared and used to create suggestions as to how government, corporate and nonprofit organizations can assist these firms to regain profitability and market share to remain competitive in the future. Given these considerations, this paper will assess the 2020 pandemic effects on Black-owned small businesses in the Hampton Roads region of Virginia. Based on the feedback from small business owners, managers and employees, recommendations will be given to help these companies move forward. The insights will be targeted to government and private organizations that create policies to promote small businesses.

\section{EXISTING RESEARCH}

There has been much research released about small businesses over the last few decades, yet academics have not yet published many articles about how the COVID-19 incident has impacted these firms. However, a few do exist with valuable information.

For example, recent studies by Fairlie (2020) found that $41 \%$ of African-American businesses lost their businesses in the first few months of the pandemic, compared to $22 \%$ of firms owned by other races. Part of this loss is because many Black-owned businesses and female-owned businesses were more likely to be in industries that were hit harder by the pandemic, such as construction, lodging, restaurants, and transportation. Most of these small firms were not prepared to weather this protracted economic downturn. A study by Bohn, Mejia, and Lafortune (2020) regarding the business environment in 2020 states that less than $20 \%$ of firms had cash to carry them over for 3 months of expenses when the virus began in the first quarter of the year. In a related study, Bartik et al. (2020) found that $43 \%$ of businesses closed temporarily due to the pandemic, and most of these firms had less than a month's worth of cash to handle expenditures.

Interestingly, practitioner and industry pieces address the obstacles faced by these firms (Stangler, 2020). The New York Federal Reserve Bank reported that only $20 \%$ of firms in areas with the highest rates of Black-owned businesses in the state received Federal pandemic assistance loans, and for similar counties, the rates were less (Effects of COVID, 2020). Thus, the aid intended to reach the most vulnerable firms did not get there. Other challenges for these businesses, which existed before the pandemic, were lower cash reserves, less reliable banking relationships, and larger gaps in funding (Da Costa, 2020). Therefore, the perfect storm of events and characteristics fueled a period of declining sales for many minority-owned companies, especially Black-owned small businesses in 2020.

Mom and Pop style restaurants and neighborhood bars, in particular, have been hard hit by the pandemic. This was partly due to the huge growth and excess capacity in the food and beverage industry in the 2010s. The National Restaurant Association estimates that nationwide over 100,000 establishments have closed temporarily or permanently due to the virus. Those who do survive have become "ghost restaurants" which have no customers inside but simply offer takeout or delivery. Some complaints of these owners are the issues of hemorrhaging money, deciding which workers to let go, how to pay the rent, and what to do when unemployment insurance runs out (Coronavirus Information, 2020). These concerns are also shared by small business owners in other industries and are amplified for Black small-business owners, who often have smaller savings and fewer resources to draw down (Four Million, 2020).

Women in the workforce have been affected more than their male counterparts, based on research studies about the pandemic. NBC News reported that 1.1 million women stepped out of the workforce in September, many of whom were small business owners. $80 \%$ of working women say they are the primary caregiver for their children, and about $40 \%$ say 
they have elder care duties for aging family members. (Working Women, 2020). In Virginia, NBC affiliate WAVYTV 10 used the term She-cession to refer to the large numbers of women who are now unemployed or underemployed as a result of economic hardships due to COVID-19. Many of these workers had to choose between staying home to home-school their children as opposed to keeping their jobs during the outbreak. Women of color are more likely to have left the workforce during the pandemic to take care of family members than other groups. And they are more likely to hold part-time jobs without benefits or healthcare (Quickfacts, 2020). This reality negatively impacts small businesses where many women work (She-cession, 2020).

\section{PROGRAMS AND AID FOR SMALL BUSINESSES}

The Federal government has issued the largest and most comprehensive programs to date to assist businesses with challenges resulting from the pandemic. The first major Federal program was the CARES Act (Corona Virus Aid, Relief and Economic Security Act) passed in March 2020. It provided \$349 billion in Small Business Administration (SBA) loans known as the Paycheck Protection Program (PPP) to allow funds to reach business owners and employees quickly (Hare, 2020). Other Federal programs include the: Economic Injury Disaster Loans (EIDL), SBA Loan Forgiveness Program, the Lost Wage Assistance Program (for unemployment due to COVID-19 and tax relief initiatives (Coronavirus Emergency, 2020; Small Business Relief, 2020). The SBA Small Business Tax Provision Program allows deferment of payroll taxes but it is not available to those firms that use the Paycheck Protection Program. The SBA also offers Express Bridge Loans, SBA Debt Relief Programs, Emergency Economic Injury Grants, as well as counseling and training for businesses with 500 or fewer employees (Resources for Small Businesses, 2020; Small Business Statistics, 2020).

Virginia's cities and counties have a wide variety of programs to assist small business owners in light of COVID19 , but they vary greatly depending on where the firm is located (Cook, 2020). For example, larger cities offered up to $\$ 10,000$ in aid while smaller cities offered a maximum of $\$ 500$ (How the Coronavirus, 2020). Some had rolling deadlines whereas others required that applicants file within 30 days. Certain localities had restrictions on which types of businesses could apply for aid, and yet others had few limitations. As a result, the location of the business and the industry in which it operated determined how much and what types of aid were available, which could make or break the small business (Smith, 2020).

In addition to government offerings, many corporations are stepping in to help small businesses. Leading corporations, such as GoDaddy, Intuit/Quick Books, and Bill.com, offered financial support to keep businesses open during the pandemic. A number of these donors require the businesses to raise their capital as a condition of receiving aid. Some offer matching funds of $\$ 500$ for each $\$ 500$ raised.
GoFundMe and Yelp made offers such as microgrants to qualifying small businesses through a Small Business Relief Initiative Fund. Amazon set up a \$5 million Neighborhood Small Business Relief Fund which was able to help numerous companies (Microgrants, 2020).

To lessen the impacts of the virus, American Express offered $\$ 10$ million in grants to Black business owners in 2020. The first phase of the program involves the company offering $\$ 5,000$ grants for up to 300 businesses in a program called "Coalition to Back Black Businesses." This is a collaborative effort between the U.S. Chamber of Commerce Foundation, the National Black Chamber of Commerce, the National Business League, the U.S. Black Chambers, and Walker's Legacy, which is planned to continue to fund firms in need for the next 4 years (Dishman, 2020). So, many options for help due to pandemic challenges exist for small businesses from corporations. But, in a recent questionnaire, most owners say that running the business takes all of their time and so they don't have to necessary hours to spend on researching the opportunities and filling out paperwork for these types of funds (Small Business Owners, 2020).

Some private organizations have come to the rescue of small businesses, but many of these firms, including Blackowned businesses, have not gotten the word, according to these donors. One nonprofit funder is the Virginia 30-day fund, initially set up for 30 days of aid in April, but it has been replenished and plans to donate through the end of 2020 (Lake, 2020). Rebuild VA is another grantor that focused on providing needed monies to small businesses in the Commonwealth (Smith, 2020). The Hello Alice Foundation offered Business for All Grants up to $\$ 50,000$ to small businesses across the country for long-term growth. However, the nonprofit did not indicate specific funds for those most affected, such as women-, veteran- or minority-owned firms (Business for All, 2020).

Some celebrities have also stepped in to help small businesses as well. Magic Johnson Enterprises donated \$100 million to female and minority-owned firms that did not receive governmental support (News, 2020). Singer Rihanna's nonprofit, The Clara Lionel Foundation, donated $\$ 5$ million to fight Coronavirus, part of which went to small businesses (What does CLF, 2020). Beyonce's BeyGOOD Foundation announced in September that she would donate $\$ 1$ million to help Black-owned small businesses. BeyGOOD partnered with the NAACP to create the Black-Owned Small Business Impact Fund to advance economic empowerment for Black businesses, donating $\$ 10,000$ to qualified firms (Gunn, 2020). In a generous gesture, Jrue Holiday, the Milwaukee Bucks allstar player, donated the rest of his annual salary in December to Black-owned small businesses and nonprofits (Montrose, 2020). And Mark Cuban, owner of the Dallas Mavericks, agreed to reimburse meals for his employees if they purchase from local independent restaurants in the area (Small Businesses, 2020). These types of aid were less obvious but did provide relief to some small businesses in Virginia. 
Though these sources were not often cited by Black small business owners as relief funds received.

\section{RESEARCH METHODOLOGY}

The present study focused on Black-owned small businesses in the Hampton Roads area of Virginia, defined as businesses with 500 employees or less (What is a Small Business, 2020). The cities of Hampton Roads include Chesapeake, Hampton, Newport News, Norfolk, Portsmouth, Suffolk, Virginia Beach, Williamsburg, and Yorktown for this piece.

These firms were contacted directly based on their listing in one of several databases available online. Some of the database websites used were: blackbrand.biz, blackbusinesslist.com, blackpagesusa.com, dailypress.com, hrchamber.com, pilotonline.com, sbsd.virginia.gov, virginiablackbusinessdirectory.com,

and virginiapeninsulachamber.com, (Gladden,2010; Localities,2020; Small Business Relief, 2020).

Black-owned small businesses were contacted in the Hampton Roads area to determine if they were interested in participating in the survey via email, mail, and phone contacts obtained from the databases. Participants were told that the purpose of the survey was to determine how they learned about and received aid for pandemic relief, and how these processes might be improved. Business owners, managers, and employees were invited to participate in the study and were notified that it was an optional process and that they could optout at any time. They were also notified that they could receive the research findings. These representatives of the firms were self-selected into the study and comprised of owners, managers, or employees. Human subjects research review protocols were followed in the survey process (Human Subjects, 2015).

The survey included closed-ended questions for the first section, where the participants were asked about how the small businesses learned about, applied for, and received assistance for pandemic relief. A second section of the survey included open-ended questions to allow respondents to use their own words to describe the actions and processes they used to find and utilize pandemic assistance. The survey could be taken anonymously or with contact information, at the choice of the participant.

The survey was available online and on paper and participants could choose which option they preferred. Only one respondent per business was allowed. The survey was

pretested on a group of 11 small business owners not involved with the study and after some revisions, it was deemed to have good validity. Then a second pretest was given to 10 business owners not involved with the study and the reliability of the measures showed acceptable results (Guion, 2002).

Four methods were used to collect data for the study. First, online surveys were offered to respondents. Second, paper surveys were offered to those who did not want to complete the survey online. Third, follow-up emails were sent to gain more insights from some of the participants who chose to identify themselves. Fourth, some phone calls were made to clarify comments or responses in the surveys when possible. Respondents were given anonymity in terms of their answers being linked to their firms.

Using the databases' listings from Summer 2020, 371 businesses were contacted to participate in the survey. In total, 205 businesses agreed to participate and 168 surveys were received. The number of usable responses was 124. Respondents included owners, managers, and employees. This result yielded a $33 \%$ response rate.

Quantitative analysis was used to determine the most frequent answers to the objective questions. Content analysis was performed on the open-ended comments given by the respondents to capture recurring issues. Some of these remarks are provided in this paper to illustrate the topics noted by the participants. Both methods of data collection were used to gain a more comprehensive and holistic picture of the businesses' engagement with pandemic assistance.

\section{RESULTS}

The findings from this research study are divided into 6 tables. The tables in this section present the results. Tables 14 give the numeric results of the survey respondents. Tables 5 and 6 give the comments provided by the small business owners, managers, and employees. Not all comments are included in this paper, but the summary statements in this section were chosen to represent the views expressed by the participants.

Table 1 shows the various methods that small businesses reported that they used to learn about aid due to the pandemic. Internet searches topped the list, followed by email, phone, or text and then using an established network to find out about sources of funds. Over half of the respondents did use social media for this purpose. The least frequent methods included radio, banks, and other sources.

Table 1.

Information Locations of Funds for Black-owned Small Businesses in Hampton Roads 2020

\begin{tabular}{|l|l|}
\hline Method of Communication & Percentage of Respondents Who Used \\
\hline Internet Search & 96 \\
\hline Email & 91 \\
\hline Phone or Text & 89 \\
\hline Network Partners & 85 \\
\hline Mail & 82 \\
\hline Word of Mouth & 77 \\
\hline Television & 70 \\
\hline Social Media & 63 \\
\hline
\end{tabular}


E-ISSN: 2469-6501

VOL: 7 , ISSUE: 7

July/2021

DOl: http://dx.doi.org/10.33642/iibass.v7n7p6

https://creativecommons.org/licenses/by/4.0/

\begin{tabular}{|l|l|}
\hline Advisor & 40 \\
\hline Radio & 25 \\
\hline Bank & 19 \\
\hline Other & 7 \\
\hline
\end{tabular}

In Table 2, many of the small business associates note six percent joined forces with other businesses to apply, while that they are still looking for aid to promote their operations. over a quarter received aid from private sources. Fourteen Nearly three-fourths of the group did apply for aid, yet over percent said that they were accepted to receive assistance but half did not receive it. Almost half of the respondents said they did not get it.

did not receive a detailed response to their applications. Thirty-

Table 2.

Survey results for Aid Received by Black Small Business Owners in Hampton Roads 2020.

\begin{tabular}{|l|l|}
\hline Pandemic Business Aid Request/Result & Percentage Reporting \\
\hline Still Plan to Apply for Aid & 90 \\
\hline Looked in to Aid Options & 87 \\
\hline Applied for Aid & 72 \\
\hline Turned down $1^{\text {st }}$ time; told to apply again & 65 \\
\hline Did not Receive Aid & 53 \\
\hline Received Sufficient Response to Aid Request & 45 \\
\hline Received Government Aid (Federal, State, Local) & 43 \\
\hline Collaborated with Others to Apply for Aid & 36 \\
\hline Received Private Aid & 29 \\
\hline Accepted for Aid but it was not Received & 14 \\
\hline
\end{tabular}

Table 3 shows the practices used by the small purchase their goods and services. Over $85 \%$ of the businesses businesses during the virus outbreak. All of the participating reduced their hours, products offered, and staff. In this survey, small business owners used personal protective equipment and over half-closed temporarily due to the pandemic in the Spring proper hygiene procedures recommended during the pandemic. and $20 \%$ closed permanently.

Nearly all businesses offered customers contactless options to

Table 3.

Survey Results for Business Practices in the Pandemic by Black Small Business Owners in Hampton Roads 2020

\begin{tabular}{|l|l|}
\hline Pandemic Business Practices Changes & Percentage Reporting \\
\hline Instituted use of PPE & 100 \\
\hline Instituted more cleaning procedures & 100 \\
\hline $\begin{array}{l}\text { Created more contactless options } \\
\text { for customers }\end{array}$ & 98 \\
\hline Reduced operating hours & 92 \\
\hline Reduced product or service offerings & 86 \\
\hline Reduced staff and staffing costs & 85 \\
\hline Offered more services online or by phone & 71 \\
\hline Changed website to reflect pandemic procedures & 64 \\
\hline Temporarily closed the business & 53 \\
\hline Closed the Business & 20 \\
\hline
\end{tabular}

Table 4 shows the sources of aid reported by the small did receive aid from nonprofits and less than 10\% obtained business associates in the survey. The majority of assistance funds from foundations. Yet the largest source, Federal came from Federal funds, followed by state and local funding, did not reach even one-third of these small governments and then private corporations. Some businesses businesses.

Table 4.

Sources of Aid for Black-owned Small Businesses in Hampton Roads in 2020

\begin{tabular}{|l|l|}
\hline Source of Aid & Percentage of Businesses That Received Aid \\
\hline Government - Federal & 30 \\
\hline Government - State or Local & 25 \\
\hline Private Corporations & 16 \\
\hline Nonprofits & 12 \\
\hline Foundations & 9 \\
\hline Other & 3 \\
\hline
\end{tabular}


In Table 5, the small business owners, managers, and the small businesses as well as their needs. Many of the employees cited several real-world issues related to pandemic statements refer to the need for follow-up services on the part assistance. Other comments explain their actions taken due to of funding organizations.

the pandemic. These remarks emphasize what is important to

Table 5.

\section{Comments Noted by Black-owned Small Businesses Regarding Aid}

\begin{tabular}{|l|}
\hline $1^{\text {st }}$ round of PPE came out on a Wednesday - if you don't apply by Friday, you don't get it \\
\hline A microbusiness without technology has a hard time finding aid, like a barber with no website \\
\hline $\begin{array}{l}\text { Requirements to spend funds in a certain way. I have an unusual cost structure so I was not able to get funding for } \\
\text { the pandemic. }\end{array}$ \\
\hline Rent assistance is needed most. \\
\hline We were just holding on. \\
\hline Restaurants were unfairly targeted. \\
\hline We know our customers - we are part of the community. \\
\hline Our 62 -year old business had to close - open since 1923. \\
\hline Walk away standing tall instead of crawling out. \\
\hline Got a PPP loan for $\$ 14,000$ - it lasted 5 weeks. \\
\hline Restaurants were offering free food to customers in a drive-thru. \\
\hline We kept the community connected during the lockdown. \\
\hline Small businesses need another federal funding package. \\
\hline Recently we sold the business for $\$ 180,000$ that was valued at $\$ 1,000,000$ 10 years ago. \\
\hline The county can offer double the gift card to entice buyers to buy in this location. \\
\hline Our employees donated supplies to the elderly and shut-ins. \\
\hline We offered coupon books with other small businesses in our strip mall to bring in customers. \\
\hline The restaurant industry as we know it is dead. \\
\hline I needed to change my application but there was no place to do that. \\
\hline There is a huge shortage of staff. \\
\hline Different types of businesses are treated differently in terms getting aid. \\
\hline The scary part is so many small businesses won't make it \\
\hline We did not know who to contact after our application was submitted. \\
\hline
\end{tabular}

Table 6 displays the concerns noted by the small to provide multiple mechanisms to inform businesses about business owners, managers, and employees as they attempted available aid. The remarks underscore the need for several to receive aid due to the pandemic. The challenges stemmed options to collect the assistance, such as virtual, in-person, and from a variety of sources. These differences highlight the need remote delivery.

Table 6.

Issues Faced by Small Businesses in Receiving Aid

We turned in application just after the deadline.

No one got back to me after I contacted them for information on assistance.

The wrong phone number was listed.

The website was down.

The mail was delayed so the application was out of date.

We had a damaged form.

The post office changed its hours so we missed the cutoff.

The wrong type of application was sent.

I sent an email with questions but did not receive a response.

My employee left a phone message.

Did not have transportation to get to the SBA office.

My county was only providing emergency services.

Only the first 100 applications were reviewed.

Customer responsibilities prevented me from applying for aid.

My business did not qualify for the aid due to restrictions.

The grant had limited funds.

This business was too large to apply

We needed help with the process.

Our business had to choose between 2 types of aid.

I learned about the program too late.

Our secretary misread the rules. 


\begin{tabular}{|l|}
\hline We were rejected. \\
\hline Fraud suspected. \\
\hline Data breach left us no time to get the necessary documents. \\
\hline Could not get through on the phone number. \\
\hline Scammers websites scared us away. \\
\hline Self-employed so no employer verification options. \\
\hline We have multiple locations so we were not sure where to file for help. \\
\hline
\end{tabular}

\section{DISCUSSION}

This article summarizes the wide-ranging effects of the COVID-19 pandemic on small businesses. The survey of Black-owned small businesses in Hampton Roads, Virginia illustrated that these professionals face greater obstacles to receiving Federal, state, and local aid than similar firms do, as documented in many news reports. Other sources of aid, such as those from nonprofits and corporations, were also harder to secure for this demographic, in part due to communication failures and lack of complete information. Details shared by these respondents show the numerous hurdles they faced in reaching out for assistance due to the pandemic as well as barriers to receiving the funds. Other comments from the group refer to the lack of follow-up services to ensure that the aid is available for the intended purposes.

Given the results of the survey, some modified actions by governments, corporations, and non-profits will be useful in the future to assist these firms. Below, a list of recommendations is provided for governments to use to better assist small businesses in their recovery from the pandemic. These procedures document the ideas given by the small business owners, managers, and employees.

\section{Recommendations to Governmental Agencies by Respondents to Help Small Businesses Thrive}

1. Have a hotline for small business owners by city/county.

2. Add languages to Small Business Administration services.

3. Reach younger small business owners by using more social media.

4. Have state small business offices collaborate with university entrepreneurship centers.

5. Cities and counties should boost resources for entrepreneurial self-sufficiency through free webinars for services such as payroll functions, accounting, and software training.

6. Assist small business owners to work on the pivot retraining firms to do something different if their business is down.

7. Help business owners to find new revenue streams.

8. Provide information on useful sources of information such as the Black Information Network.

9. Direct assistance to the types of businesses reported: food/beverage, retail, manufacturing, personal services, hospitality, retail, information services, construction.

10. Offer tax relief for small businesses.
11. Increase advertisements to alert business owners about aid.

12. Offer workshops and classes in key business functions.

13. Don't overlook funding for certain industries just because others have preferences (such as entertainment).

14. Have pickup locations for personal protective equipment readily accessible.

15. Hold back some funding to avoid running out when some business cycles are nontraditional.

16. Go over the application with the applicant before it is turned in to improve outcomes.

Next suggestions are given for donor organizations to use to improve the process for small businesses to receive aid to enhance market performance. These ideas come from the survey participants. One repeated comment was the desire to have an "other" category for unique businesses that may not fit into fixed categories.

\section{Suggestions for Economic Assistance Organizations to Improve Aid to Minority Small Business Owners}

1. Offer computer literacy seminars with ongoing coaching.

2. First come first served favors existing and established businesses - try using entry times instead.

3. Underbanked and underserved businesses are left out of the assistance process.

4. Manufacturers and construction businesses were helped at the expense of the hospitality industry.

5. Some businesses were able to apply for 5 or more types of aid. Some businesses did not qualify to apply for any type of aid.

6. Online businesses seem to be overlooked for many types of aid. Offer more incentives for these firms.

7. We need similar programs among cities and counties At this time, the wealthy cities have more aid to offer.

8. Not all localities had assistance to offer small businesses.

9. Aid forms in languages other than English and Spanish are needed.

10. Liaisons would be helpful to get more aid to the smallest businesses so the entrepreneurs can continue to run their businesses.

11. Outreach programs and better marketing are needed to reach minority-owned small businesses.

12. Grace periods should be allowed, especially in multistep processes to receive aid.

13. Our business does not match the allowed categories on the form. 
14. We could never get an in-person appointment at our local economic development office.

According to SCORE, the Service Corps of Retired Executives, as of Fall 2020, 8.8\% of Black-owned businesses in the U.S. categorized themselves as profitable and growing, versus $15 \%$ of White-owned businesses. Reasons given for market slowdowns among these small businesses included: the mandate to work remotely, COVID-19 in the owner's family, COVID-19 among staff, health issues for the owner's family, health issues for staff, and the inability to find daycare (Megaphone, 2020). Yet, despite these challenges, 64\% of Black business owners were optimistic about the future for their firms in 2020 (Newport and McMurray, 2020).

Some limitations of this study include the use of crosssectional data and a small sample size. These issues may be corrected with follow-up studies that extend the survey to other geographic areas and other periods. Future work could also include additional relevant factors such as female- or veteranowned small businesses. The lack of a comprehensive database of Black-owned small businesses is another obstacle that may be corrected. With the creation of such a resource, this asset would encourage more scholarly work in the area.

\section{CONCLUSION}

Small businesses benefit the local community in many ways. This is especially true for Black-owned businesses, as they often serve not only as vendors of goods and services but also as sources of information, networking, and civic engagement that keep societies thriving.

Amid the pandemic, The Wall Street Journal reported increased interest and business activity at Black-owned businesses in the United States in 2020. This was due in part to the Black Lives Matter movement, racial justice protests held across the country, as well as notoriety surrounding the Juneteenth holiday nationwide, which marks the emancipation of the last slaves in the United States (Burton, 2020). 2020 was an unusual year for several reasons. The pandemic topic cannot be discussed without also mentioning the racial concerns facing the United States as a result of police brutality towards Black Americans. This trend also impacted Blackowned small businesses in a year that was already difficult for them. It is a complex issue, but the focus on Black Americans as a result of the Black Lives Matter protests in 2020 should highlight Black-owned businesses and bring attention, resources, and customers to their stores. It is up to the government, corporate, religious, media, and community leaders to ensure that this progress is emphasized, supported, and sustained. Ideally, scholarly pieces such as this one will also highlight the need to keep Black-owned businesses innovating and prospering in all environments.

In summary, this research revealed that in the Hampton Roads region of Virginia the 2020 pandemic affected all Black-owned small businesses in the study in a negative way. Some businesses reported major challenges in responding to the situation, while others reported less dramatic hurdles to overcome. However, the results show that Black small business owners had significant obstacles to receiving aid from all types of organizations. The paper also makes suggestions as to how government, corporate, nonprofit and other donor organizations can assist these firms in dealing with the current environment and preparing for stability and growth in the future.

Due to the significant COVID-19 impacts on minorityowned firms, many business experts agree that public policy experts need to consider the myriad issues facing these organizations to correct economic disparities, wealth creation, and job losses, which have hit the Black community and therefore Black-owned companies harder than others (Fairlie, 2020). Public policy changes can help address wealth inequities, job skills training, entrepreneur funding, start-up ecosystems, and economic regional cooperation for Blackowned small businesses where these efforts will yield longterm benefits to these markets. With the dedicated effort to Black small businesses, the U.S. Government and other organizations can enact processes to ensure that they are viable and profitable for generations to come.

\section{ACKNOWLEDGEMENT}

The author would like to acknowledge support for this project in the form of a research grant from the Center for African American Public Policy at Norfolk State University.

\section{REFERENCES}

ABS Release Provides Data on Minority- and Women-Owned Businesses. (2019). U. S. Census. Retrieved October 10, 2020 from http://www.census.gov

Bartik, A., Bertrand, M., Cullen, Z., Glaeser, E., Luca, M., \& Stanton, C. (2020). How are Small Businesses Adjusting to COVID-19? Early Evidence from a Survey. National Bureau of Economic Research. Working Paper No. w26989. Retrieved September 7, 2020 from http://www.nber.org

Black Businesses Respond to the Pandemic. (2020, November 24). WAVY News 10. Retrieved November 30, 2020 from http://www.wavy.com

Bohn, S., Mejia, M., \& Lafortune, J. (2020). The Economic Toll of COVID-19 on Small Businesses. Public Policy Institute of California. 
Business for All Grants. (2020, June 1). Retrieved from http://www.helloalice.com

Cook, S. (2020, April 10). Resources to help businesses navigate uncertain times. Retrieved September 30 at http://dailypress.com

Coronovirus Emergency Loans Small Business Guide and Checklist (2020). U.S. Chamber of Commerce. Retrieved October 30, 2020 from http://www.uschamber.com

Coronavirus Information and Resources. (2020). National Restaurant Association. Retrieved September 30, 2020 from http://www.restaurant.org

Cox, J. (2020, August 4). Black-Owned Businesses Hit Harder During Pandemic and Need More Aid, Fed Paper Says. CNBC. Retrieved September 30, 2020 from http://cnbc.com

Da Costa, P. (2020). The COVID-19 Crisis Has Wiped Out Nearly Half of Black Small Businesses Forbes. Retrieved October 10, 2020 from http://www.forbes.com

Dishman, L. (2020, September 15). American Express Pledges \$10 Million for Grants to Black Business Owners. Retrieved September 30, 2020 from http://www.fastcompany.com

Effects of COVID on Small Businesses. (2020, August). Economic Research Division. Retrieved September 30, 2020 from http://newyorkfed.org

Fairlie, R. (2020). The impact of COVID-19 on small business owners: Evidence of early-stage losses from the April 2020 current population survey. National Bureau of Economic Research. Working Paper 27309. Retrieved September 7, 2020 from http://www.nber.org

Four Million Small Businesses Forced to Close. (2020, November 15). Retrieved November 20, 2020 from www.msn.com

Gladden, S. (2010, March 11). Local Black-owned businesses. Daily Press. Retrieved October 30, 2020 at http://dailypress.com

Gunn, T. (2020, September 3). Beyonce Donates Additional \$3 Million to Help Black-Owned Businesses. Retrieved from http://www.revolt.tv.news

Guion, R. (2002). Validity and Reliability. In S. Rogelberg (Ed.), Blackwell Handbooks of Research Methods in Psychology. Handbook of Research Methods in Industrial and Organizational Psychology. Blackwell Publishing, (pp.50-82).

Guitierrez, G. (2020, December 16). Racial Inequities and the Pandemic. NBC News. Retrieved December 17, 2020 from http://www.nbcnews.com

Hare, N. (2020, April 3). Newly Available CARES Act Loans: 10 Things Small Businesses Need to Know. All Business: Your Small Business Advantage. Retrieved September 15, 2020 from http://www.allbusiness.com

How the Coronavirus has Affected Small Businesses in Hampton Roads. (2020, December 13). WAVY 10 News. Retrieved December 16, 2020 from http://www.wavy.com

Human Subjects in Research: Things to Consider. Managing Grants. (2018). National Institute of Mental Health. Retrieved May 30, 2020 from http://www.nimh.nih.gov

Kendi, I. (2020, April 6). What the racial data show. The Atlantic. Retrieved August 10, 2020 at http://theatlantic.com

Lake, S. (2020, July 1). Virginia 30 Day Fund Makes 500th Grant. Retrieved September 30, 2020 from

http://virginiabusiness.com

Localities with Stimulus Programs. (2020). Virginia Department of Small Business and Supplier Diversity. Retrieved September 30, 2020 from http://sbsd.virginia.gov

Macro Issues: Congress Can’t Agree. (2020, September 15). New York Times. Retrieved September 20, 2020 from http://nytimes.com

Mahajan, D. (2020, July 30). Protecting small businesses from the impact of COVID-19. McKinsey and Company. Retrieved November 22, 2020 at http://www.mckinsey.com

Megaphone of Main Street: The Impact of COVID-19, Infographic \#2 - Impact on Black-Owned Small Businesses. (2020, October 5). SCORE. Retrieved October 10, 2020 from http://www.score.org

Microgrants and Fundraising Tools to Qualifying Small Businesses (2020, April 7). Forbes. Retrieved September 15, 2020 from http://www.forbes.com

Montrose, A. (2020, December 19). Jrue Holiday Donates the Rest of His 2020 NBA Salary to Black-Owned Small Businesses and Nonprofits. Retrieved December 20, 2020 from http://complex.com/sports. 
National Resources and Policy Updates for Small Businesses Impacted by COVID-19 (2020, April 16). Society Corps of Retired Executives. Retrieved September 19, 2020 from http://score.org

Newport, F. \& McMurray, C. (2020, September 9). Small-Business Owners' Optimism Up from April, Below Pre- COVID-19. Retrieved September 30, 2020 from http://news.gallup.poll

News. (2020, July 5). Magic Johnson Foundation. Retrieved September 30, 2020 from http://magicjohnson.com

Quickfacts. (2020). U.S. Census Bureau. Retrieved September 30 from http://census.gov

Resources for Small Businesses in Response to the Novel Coronavirus Pandemic. (2020, June 8). Small Business Administration, Office of Advocacy. Retrieved September 30, 2020 from http://advocacy.sba.gov

Rogers, K. (2020, December 17). Effects of the Pandemic on Small Businesses. CNBC. Retrieved December 17, 2020 from http://cnbc.com

She-cession. (2020, December 8). Women in Business Face Unemployment and Underemployment. Retrieved December 8, 2020 at http://wavy.com

Shepherd, M. (2020, December 16). 2019 and 2020 Business Statistics. Retrieved December 17, 2020 from http://www.fundera.com

Small Businesses and the Pandemic. (2020). Retrieved October 3, 2020 from http://www.cnbc.com

Small Business Owners Discuss the Effects of Coronoavirus Pandemic. (2020, October 19). ABC News. Retrieved October 30 , 2020 from http://www.abc7news.com.

Small Business Relief Packages. (2020, October 1). Retrieved October 8, 2020 from http://pilotonline.com

Small Business Statistics (2020). U.S. SBA Office of Advocacy. Retrieved October 10, 2020 from http://www.sba.gov

Smith, H. (2020, October 28). Small Businesses and Nonprofits Encouraged to Apply for Rebuild VA Grant. Retrieved October 30, 2020 from http://nbc12.com

Smith, K. (2020, May 26). Our Big List of COVID-19 Assistance Programs. Institute for Self-Reliance. Retrieved October 10, 2020 at http://www.ilsr.org

Stangler, D. (2020, August 8). How are Small Businesses and Entrepreneurs Faring Today in COVID-19 Downturn?

Forbes. Retrieved September 30, 2020 from http://www.forbes.com

Statements and Letters. (2020, December 7). Independent Restaurant Coalition. Retrieved December 10, 2020 from http://saverestaurants.com

What does CLF Stand for? Clara Lionel Foundation. (2020, June 10). Retrieved September 30 from http://fentybeauty.com

What is a Small Business and What Sectors Have the Most of Them? USA Facts. Retrieved September 30, 2020 from http://www.usafacts.org

Working Women and the Virus (2020, October 28). NBC News. Retrieved November 10, 2020 from http://www.nbcnews.com 